\title{
STUDI ALTERNATIF PENAGGULANGAN GENANGAN BERBASIS KONSERVASI DI SISTEM DRAINASE OESAPA-LASIANA KOTA KUPANG
}

\author{
Mauluddin Sebandar ${ }^{1}$, Mohammad Bisri ${ }^{2}$, Sumiadi $^{2}$ \\ ${ }^{1}$ Mahasiswa Magister Teknik Pengairan, Fakultas Teknik, Universitas Brawijaya, Malang \\ ${ }^{2}$ Dosen Jurusan Teknik Pengairan, Fakultas Teknik, Universitas Brawijaya, Malang \\ Jurusan Pengairan Fakultas Teknik Universitas Brawijaya Jalan MT. Haryono 167 Malang \\ Email : ${ }^{1}$ idinsknight2012@gmail.com
}

\begin{abstract}
ABSTRAK: Sistem drainase berbasis konservasi merupakan konsep pengelolaan air hujan dan limpasannya pada sistem drainase perkotaan, dengan tujuan meningkatkan daya guna air, meminimalkan kerugian serta konservasi lingkungan. Penelitian ini bertujuan untuk menganalisa kapasitas dimensi saluran drainase eksisting di sistem drainase Oesapa - Lasiana Kota Kupang, mengetahui alternatif penanganan genangan yang berbasis konservasi di lokasi studi tersebut. Dalam menganalisa hal tersebut, digunakan software Storm Water Management Model (SWMM) versi 5.1 untuk memodelkan limpasan hujan kala ulang 5 tahun dengan membandingkan kondisi jaringan drainase sebelum dan sesudah penerapan kolam retensi, sumur resapan dan melebarkan/meninggikan dimensi saluran eksisting. Untuk menangani permasalahan genangan di lokasi studi dibutuhkan 1 unit kolam resapan berukuran 160 m x 100 m x 3 m, dan 587 unit sumur resapan berdiameter $1 \mathrm{~m}$, kedalaman 3 meter serta melebarkan / meninggikan dimensi saluran eksisting menjadi $1.60 \mathrm{~m}$ x $0.80 \mathrm{~m}$ sepanjang $706 \mathrm{~m}$. Sumur resapan direncanakan dipasang di tiap - tiap rumah warga berbentuk lingkaran, terbuat dari pasangan batu bata tanpa diplester. Data curah hujan selama 16 tahun (2001-2016) dari stasiun Lasiana dan stasiun El Tari Kupang dipakai untuk melakukan simulasi hujan rancangan. Perhitungan intensitas hujan dengan durasi 6 jam kala ulang 5 tahun menggunakan rumus Mononobe dan menghasilkan kurva IDF. Dari kurva IDF dibuat distribusi hujan jam-jaman (hyetograph) kala ulang 5 tahun sebesar $128.88 \mathrm{~mm}$ yang kemudian dipakai sebagai masukan parameter SWMM. Hasil kalibrasi model menunjukkan nilai RMSE antara debit pemodelan dengan debit terukur sebesar 0.061405 (6.14\%). Hasil simulasi SWMM menunjukkan kapasitas saluran drainase eksisting di lokasi studi tidak mampu menampung hujan rancangan dengan kala ulang 5 tahun dan mengakibatkan genangan di 18 conduit.
\end{abstract}

Kata kunci: konservasi, SWMM,drainase,pemodelan,alternatif,limpasan

ABSTRACT: Conservation-based drainage system is the concept of rainwater management and its runoff on urban drainage system, for improving water efficiency, minimizing loss and environmental conservation. This study aims are to analyze the capacity of existing drainage dimension in Oesapa - Lasiana City of Kupang drainage system, to analyze the alternative of conservation-based to handle the inundation problem. It is used SWMM to analyze the rainfall model over the 5 year return period by comparing the drainage network conditions before and after the application of retention pond, injection well and widening the existing channel dimensions. To solve inundation problem, it needed 1 unit of retention pond is $160 \mathrm{~m} \times 100 \mathrm{~m} \times 3$ $\mathrm{m}$, and 587 units of injection well $1 \mathrm{~m}$ in diameter, $3 \mathrm{~m}$ depth and widened the existing channel dimension to $1.60 \mathrm{~m} \times 0.80 \mathrm{~m}$ along $706 \mathrm{~m}$. The circle injection well are planned to be installed in each house, made of brick pairs without plaster. Rainfall data for 16 years (2001-2016) from Lasiana station and El Tari Kupang station were used to simulate the rainfall design. Rain intensity calculation with a duration of 6 hours when a 5 year return period using the Mononobe formula and and produces IDF curves. From the IDF curve, a 5 year return period time 
distribution of $128.88 \mathrm{~mm}$ is used as input of SWMM parameters. The model calibration results show the RMSE value between the modeling discharge and the measured discharge of 0.0614 (6.14\%). The SWMM simulation results show that existing drainage capacity at the study site was not able to accommodate the design rainfall with a 5 year return period and resulted in a puddle in 18 conduits.

Keywords: conservation, SWMM, drainage, modelling, alternative, run off

Pengembangan permukiman dan kegiatan industri di perkotaan yang demikian pesatnya mengurangi daerah resapan air hujan, tidak terencananya dengan baik sistem drainase yang ada serta laju urbanisasi penduduk yang tinggi sehingga memerlukan lahan hunian yang pada akhirnya daerah resapan air hujan menjadi lebih sempit (Lo Russo, 2009).

Daerah genangan limpasan air hujan di wilayah kota Kupang, diantaranya adalah di kawasan padat penduduk Oesapa-Lasiana. Adapun faktor penyebab genangan di kawasan tersebut diantaranya adalah:

1. Sistem drainase yang ada, belum terencana dengan baik dan berkesinambungan.

2. Adanya perumahan yang padat penduduk di daerah berkontur rendah.

3. Pembangunan di kawasan Oesapa-Lasiana yang sangat pesat, berdampak pada jumlah daerah resapan yang semakin sempit.

4. Tidak terdapat lahan yang cukup memadai untuk dilakukannya peningkatan kapasitas saluran drainase eksisting.

5. Kurangnya kesadaran masyarakat dan juga instansi terkait tentang pentingnya daerah resapan sebagai alternatif penanggulangan genangan dan juga upaya konservasi air. adalah: Tujuan yang ingin dicapai dari studi ini

1. Mengetahui hasil analisa kapasitas dimensi saluran drainase eksisting di sistem drainase Oesapa-Lasiana kota Kupang .

2. Mengetahui penanganan genangan yang berbasis konservasi dari hasil analisa kapasitas tampungan drainase eksisting di lokasi studi.

\section{METODE PENELITIAN}

\section{Kondisi Daerah Studi}

Penelitian ini dilakukan di sistem drainase Oesapa-Lasiana yang sebagian besar berada di wilayah Kecamatan Kelapa Lima Kota Kupang. Diketahui bahwa luas sistem drainase Oesapa-Lasiana adalah 652,95 ha atau 6,53 $\mathrm{km}^{2}$, dengan dominasi penggunaan lahan untuk bangunan perumahan dan sisanya berupa ruang terbuka hijau serta fasilitas umum lainnya.

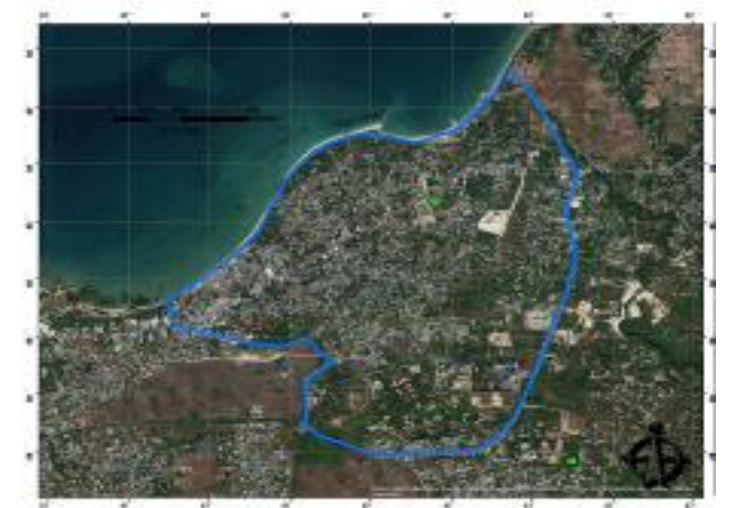

Gambar 1. DTA Sistem Drainase Oesapa-Lasiana

\section{Tahapan Penelitian}

Tahapan penelitian dan langkah pemodelan menggunakan SWMM 5.1 adalah sebagai berikut:

1. Menentukan batasan luas sub daerah tangkapan aliran / Sub DTA, luas daerah tidak kedap air dan kedap air serta kemiringan lahan berdasarkan peta topografi dan peta tata guna lahan.

2. Dari data dan peta jaringan drainase eksisting dapat ditentukan arah aliran air dan dimensi saluran. Survey lapangan dengan melakukan pengukuran terhadap kemiringan dan elevasi dasar saluran eksisting di lokasi studi.

3. Membuat model limpasan hujan kondisi eksisting dengan SWMM 5.1 dan dengan menggunakan uji statistik Root Mean Square Error (RMSE) untuk mengukur tingkat keakurasian prakiraan model tersebut. Nilai RMSE yang dihasilkan apabila mendekati ke angka 0 (nol) menunjukkan bahwa variasi nilai yang dihasilkan oleh suatu model prakiraan mendekati variasi nilai observasinya.

4. Melakukan uji konsistensi data curah hujan dengan analisis Rescaled Adjusted Partial Sums (RAPS) karena kurang dari 3 (tiga) stasiun penakar hujan (Sri Harto, 2000).

5. Analisa Frekuensi Menggunakan distribusi Log Person Tipe III untuk menganalisa frekuensi data intensitas hujan kala ulang 5 tahun.

6. Uji Kesesuaian Distribusi 
Uji kesesuaian distribusi menggunakan Uji ChiKuadrat dan Uji Smirnov-Kolmogorov. Uji ini untuk menentukan apakah persamaan distribusi yang dipilih dapat mewakili distribusi statistik sampel data yang akan dianalisis.

7. Membuat lengkung intensitas-durasi hujan. Perhitungan menggunakan rumus Modified Mononobe (Sosrodarsono dan Takeda, 1983) dengan persamaan : $I=\frac{R_{24}}{t}\left(\frac{t}{T}\right)^{2 / 3}$

8. Evaluasi kinerja saluran drainase eksisting menggunakan simulasi curah hujan - limpasan dengan SWMM 5.1.

9. Merencanakan lokasi penempatan, jumlah dan dimensi kolam retensi, sumur resapan serta peningkatan kapasitas saluran eksisting.

10. Simulasi kondisi eksisting saluran drainase dan selanjutnya melakukan simulasi curah hujanlimpasan dengan SWMM 5.1 pada skenario penerapan kolam retensi, sumur resapan dan peningkatan kapasitas saluran eksisting secara bersamaan.

\section{HASIL DAN PEMBAHASAN}

\section{Analisa Hidrologi}

\section{Uji Konsistensi Data Hujan}

Metode Rescaled Adjusted Partial Sums (RAPS) digunakan untuk menguji konsistensi data hujan pada stasiun individual (stand alone station) dengan perhitungan seperti yang ditampilkan pada Tabel 1 untuk stasiun hujan Lasiana dan Tabel 2 untuk stasiun hujan El Tari berikut.

Tabel 1. Uji Konsistensi Data Hujan Stasiun Lasiana

\begin{tabular}{|c|c|c|c|c|c|c|}
\hline \multirow{2}{*}{ No } & \multirow{2}{*}{ Tahun } & Hujan & \multirow{2}{*}{$S k^{*}$} & \multirow{2}{*}{$D_{y}^{2}$} & \multirow{2}{*}{$\mathrm{Sk}^{* *}$} & \multirow{2}{*}[\mathrm{Sk}^{**}]{} \\
\hline & & $\mathrm{mm} / \mathrm{hari}$ & & & & \\
\hline 1 & 2001 & 128.00 & 4.25 & 1.13 & 0.10 & 0.10 \\
\hline 2 & 2002 & 98.00 & -25.75 & 41.44 & -0.60 & 0.60 \\
\hline 3 & 2003 & 203.00 & 79.25 & 392.54 & 1.86 & 1.86 \\
\hline 4 & 2004 & 55.00 & -68.75 & 295.41 & -1.61 & 1.61 \\
\hline 5 & 2005 & 79.00 & -44.75 & 125.16 & -1.05 & 1.05 \\
\hline 6 & 2006 & 193.00 & 69.25 & 299.72 & 1.62 & 1.62 \\
\hline 7 & 2007 & 113.00 & -10.75 & 7.22 & -0.25 & 0.25 \\
\hline 8 & 2008 & 170.00 & 46.25 & 133.69 & 1.08 & 1.08 \\
\hline 9 & 2009 & 173.00 & 49.25 & 151.60 & 1.15 & 1.15 \\
\hline 10 & 2010 & 100.00 & -23.75 & 35.25 & -0.56 & 0.56 \\
\hline 11 & 2011 & 78.00 & -45.75 & 130.82 & -1.07 & 1.07 \\
\hline 12 & 2012 & 100.00 & -23.75 & 35.25 & -0.56 & 0.56 \\
\hline 13 & 2013 & 139.00 & 15.25 & 14.54 & 0.36 & 0.36 \\
\hline 14 & 2014 & 111.00 & -12.75 & 10.16 & -0.30 & 0.30 \\
\hline 15 & 2015 & 154.00 & 30.25 & 57.19 & 0.71 & 0.71 \\
\hline 16 & 2016 & 86.00 & -37.75 & 89.07 & -0.88 & 0.88 \\
\hline \multicolumn{2}{|c|}{ Jumlah } & 1980.00 & & 1820.19 & & 0.00 \\
\hline \multicolumn{2}{|c|}{ Rerata } & 123.75 & & & & \\
\hline
\end{tabular}

$$
\begin{aligned}
& \mathrm{n}=16 \\
& \mathrm{D}_{\mathrm{y}} \quad=21.8 \\
& \mathrm{Q}=|\mathrm{Sk} * \mathrm{mak}|=1.86 \\
& \mathrm{R}=\begin{array}{l}
\mathrm{Sk}^{* *} \mathrm{mak}- \\
\mathrm{Sk} * \mathrm{~min}
\end{array} \quad=\quad 3.47 \\
& \mathrm{Q} /\left(\mathrm{n}^{0.5}\right)=0.46<1.08 \quad 90 \% \Rightarrow 0 \mathrm{k} \text { ! } \\
& \mathrm{R} /\left(\mathrm{n}^{0.5}\right)=0.87<1.29 \quad 90 \% \Rightarrow \quad \Rightarrow \quad \mathrm{k} \text { ! }
\end{aligned}
$$

\begin{tabular}{|c|c|c|c|c|c|c|}
\hline \multirow{2}{*}{ No } & \multirow{2}{*}{ Tahun } & Hujan & \multirow{2}{*}{ Sk* } & \multirow{2}{*}{$\mathrm{D}_{y}{ }^{2}$} & \multirow{2}{*}{ Sk** } & \multirow{2}{*}[\mathrm{Sk}^{**}]{} \\
\hline & & $\mathrm{mm} /$ hari & & & & \\
\hline 1 & 2001 & 160.00 & 11.15 & 7.77 & 0.202 & 0.202 \\
\hline 2 & 2002 & 115.00 & -33.85 & 71.61 & -0.613 & 0.613 \\
\hline 3 & 2003 & 195.00 & 46.15 & 133.11 & 0.835 & 0.835 \\
\hline 4 & 2004 & 133.00 & -15.85 & 15.70 & -0.287 & 0.287 \\
\hline 5 & 2005 & 125.00 & -23.85 & 35.55 & -0.432 & 0.432 \\
\hline 6 & 2006 & 210.00 & 61.15 & 233.71 & 1.107 & 1.107 \\
\hline 7 & 2007 & 130.00 & -18.85 & 22.21 & -0.341 & 0.341 \\
\hline 8 & 2008 & 145.00 & -3.85 & 0.93 & -0.070 & 0.070 \\
\hline 9 & 2009 & 182.00 & 33.15 & 68.68 & 0.600 & 0.600 \\
\hline 10 & 2010 & 100.00 & -48.85 & 149.15 & -0.884 & 0.884 \\
\hline 11 & 2011 & 302.00 & 153.15 & 1465.93 & 2.772 & 2.772 \\
\hline 12 & 2012 & 83.70 & -65.15 & 265.28 & -1.179 & 1.179 \\
\hline 13 & 2013 & 193.00 & 44.15 & 121.83 & 0.799 & 0.799 \\
\hline 14 & 2014 & 96.90 & -51.95 & 168.68 & -0.940 & 0.940 \\
\hline 15 & 2015 & 127.00 & -21.85 & 29.84 & -0.395 & 0.395 \\
\hline 16 & 2016 & 84.00 & -64.85 & 262.85 & -1.174 & 1.174 \\
\hline \multicolumn{2}{|c|}{ Jumlah } & 2381.60 & & 3052.82 & & \\
\hline \multicolumn{2}{|c|}{ Rerata } & 148.85 & & & & \\
\hline
\end{tabular}

Tabel 2. Uji Konsistensi Data Hujan Stasiun El Tari

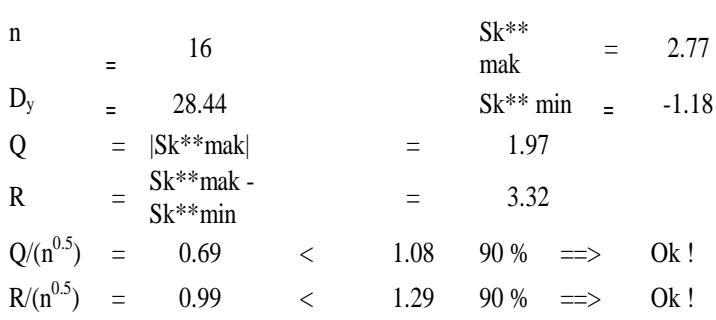

\section{Hubungan Intensitas Hujan - Waktu}

Apabila data hujan jangka pendek tidak tersedia maka lengkung intensitas dibuat menggunakan rumus Mononobe. Diketahui curah hujan rancangan harian maksimum kala ulang 5 tahun sebesar 128.88 $\mathrm{mm}$, maka dapat dihitung intensitas hujan jam-jaman seperti yang ditampilkan pada Tabel 3 .

Tabel 3 Hubungan Intensitas Hujan -Waktu Kala Ulang 5 Tahun

\begin{tabular}{|c|c|}
\hline $\begin{array}{c}\text { Durasi } \\
\text { (jam) }\end{array}$ & Intensitas Hujan (mm/jam) \\
\hline 1 & 44.68 \\
\hline 2 & 28.15 \\
\hline 3 & 21.48 \\
\hline 4 & 17.33 \\
\hline 5 & 15.28 \\
\hline 6 & 13.53 \\
\hline
\end{tabular}

Sumber: Hasil perhitungan 


\section{Keterangan :}

1. Diketahui bahwa curah hujan rancangan kala ulang 5 tahun sebesar $128.88 \mathrm{~mm}$

2. Menghitung curah hujan satu jam

$$
\begin{aligned}
& I=\frac{R_{24}}{24}\left[\frac{24}{t}\right]^{2 / 3}= \\
& \frac{128.88}{24}\left[\frac{24}{1}\right]^{2 / 3}=44.68 \mathrm{~mm}
\end{aligned}
$$

Dengan demikian bisa diperoleh grafik lengkung intensitas hujan durasi selama 6 jam seperti pada Gambar 2 berikut ini.

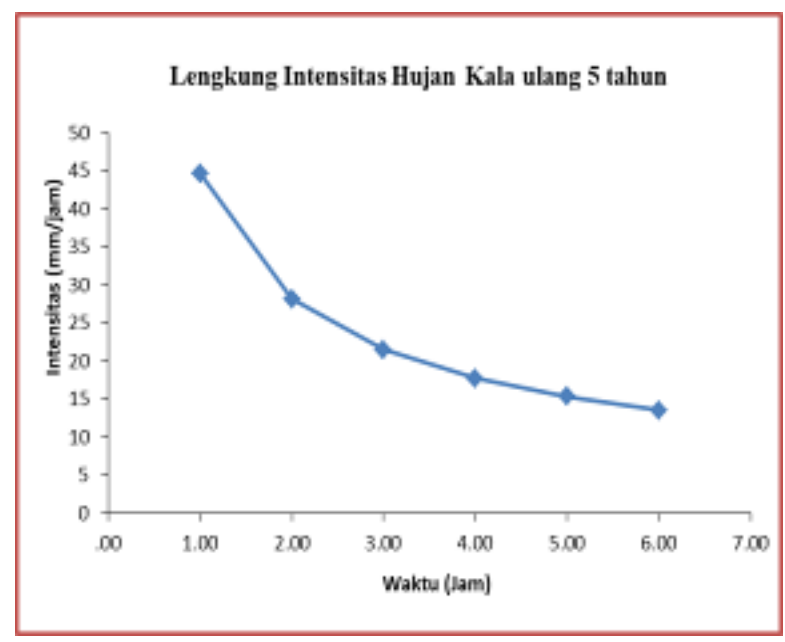

Gambar 2. Grafik lengkung Intensitas Hujan

Perhitungan hyetograph hujan rencana dengan kala ulang 5 tahun dapat dilihat pada Tabel 4 berikut ini.

\begin{tabular}{|c|c|c|c|c|c|c|c|}
\hline \multirow{2}{*}{$\begin{array}{c}\mathrm{Td} \\
(\mathrm{jam})\end{array}$} & \multirow{2}{*}{$\begin{array}{c}\Delta t \\
(j a m)\end{array}$} & \multirow{2}{*}{$\begin{array}{c}\mathrm{It} \\
(\mathrm{mm} / \mathrm{jam})\end{array}$} & \multirow{2}{*}{$\begin{array}{l}\text { It Td } \\
(\mathrm{mm})\end{array}$} & \multirow{2}{*}{$\begin{array}{c}\Delta \mathrm{p} \\
(\mathrm{mm})\end{array}$} & \multirow{2}{*}{$\begin{array}{c}\mathrm{pt} \\
(\%)\end{array}$} & \multicolumn{2}{|c|}{ hyetograph } \\
\hline & & & & & & $(\%)$ & $(\mathrm{mm})$ \\
\hline [1] & [2] & [3] & [4] & [5] & [6] & [7] & {$[8]$} \\
\hline 1 & $0 \sim 1$ & 44.68 & 44.68 & 44.68 & 55.03 & 6.75 & 8.7 \\
\hline 2 & $1 \sim 2$ & 28.15 & 56.29 & 11.61 & 14.30 & 10.03 & 12.9 \\
\hline 3 & $2 \sim 3$ & 21.48 & 64.44 & 8.15 & 10.03 & 55.03 & 70.9 \\
\hline 4 & $3 \sim 4$ & 17.73 & 70.93 & 6.49 & 7.99 & 14.30 & 18.4 \\
\hline 5 & $4 \sim 5$ & 15.28 & 76.40 & 5.48 & 6.75 & 7.99 & 10.3 \\
\hline 6 & $5 \sim 6$ & 13.53 & 81.19 & 4.79 & 5.90 & 5.90 & 7.6 \\
\hline \multicolumn{4}{|l|}{ Jumlah } & 81.19 & 100 & 100 & 128.88 \\
\hline
\end{tabular}

Tabel 4 Hitungan Hyetograph dengan metode ABM

Sumber: Hasil perhitungan

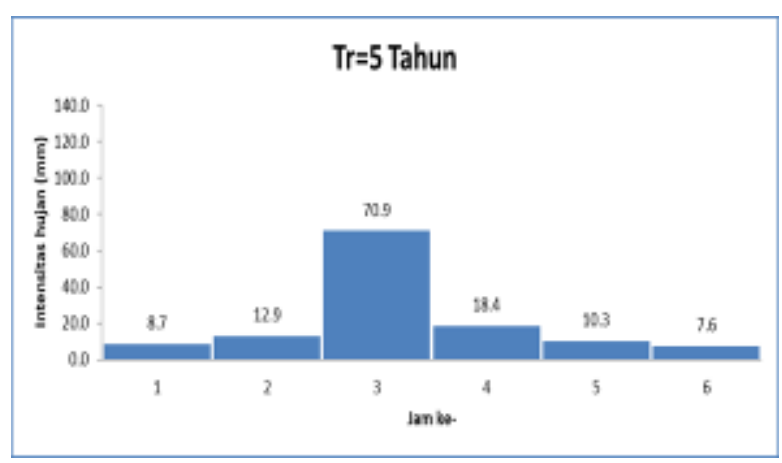

Gambar 3. Hyetograph Hujan Rencana

\section{Kalibrasi Model}

Untuk kalibrasi model, dilakukan dengan tahapan sebagai berikut:

1. Data pengukuran diambil pada kejadian hujan tanggal 18 Pebruari 2018 dengan menggunakan metode apung untuk mendapatkan besar nilai kecepatan aliran air dan mengukur kedalaman basah di dalam saluran/conduit $\mathrm{C} 1$ yang menuju outfall 1 . Dari hasil pengukuran yang dilakukan bisa dihitung nilai debit di saluran C1 selama 160 menit dengan interval waktu 10 menitan.

2. Melakukan simulasi debit saluran/conduit $\mathrm{C} 1$ di SWMM dengan menggunakan data hujan pada tanggal 18 Pebruari 2018 untuk mendapatkan nilai debit di conduit $\mathrm{C} 1$.

3. Membandingkan nilai debit hasil pengukuran di lapangan dengan nilai debit hasil simulasi di SWMM. Dalam melakukan perbandingan debit pengukuran dengan debit simulasi digunakanlah metode RMSE (Root Mean Square Errors).

4. Dari hasil perhitungan diperoleh nilai RMSE sebesar 0.061405 (sudah mendekati angka nol). Hal ini dapat menunjukkan bahwa parameter-parameter yang digunakan dalam pemodelan SWMM memiliki pendekatan yang cukup baik bila dibandingkan dengan kondisi yang ada di lapangan. Grafik Perbandingan hidrograf debit observasi/pengukuran lapangan dengan debit simulasi SWMM di saluran/conduit C1 dapat dilihat pada Gambar 4 berikut ini.

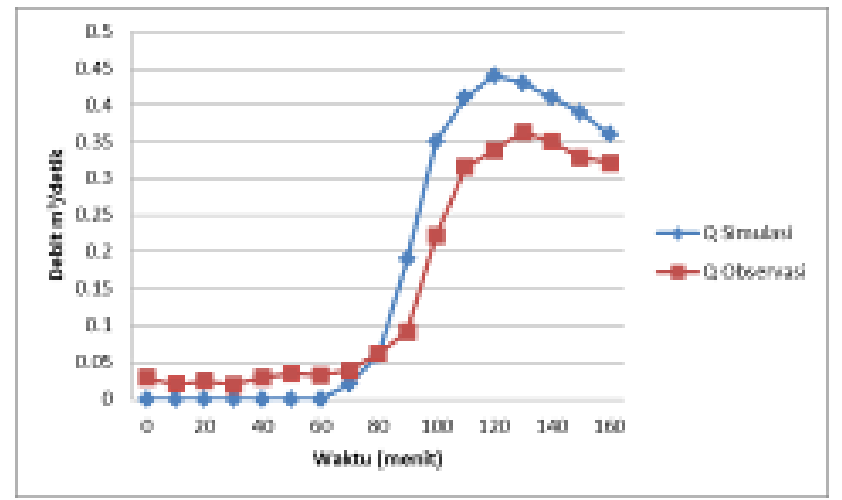

Gambar 4. Perbandingan hidrograf debit pengukuran dengan debit simulasi SWMM pada saluran/conduit $\mathrm{C} 1$

\section{Skematisasi Sistem Drainase untuk Kondisi Eksisting Sebelum Penanganan Genangan}

Selanjutnya adalah melakukan simulasi di model SWMM pada kondisi jaringan drainase eksisting dengan memasukkan hujan rancangan kala ulang 5 tahun sebagai Inputannya. 
Skema jaringan drainase dengan kondisi eksisting bisa dilihat pada Gambar 5 berikut. Sedangkan, peta genangan di DTA Oesapa-

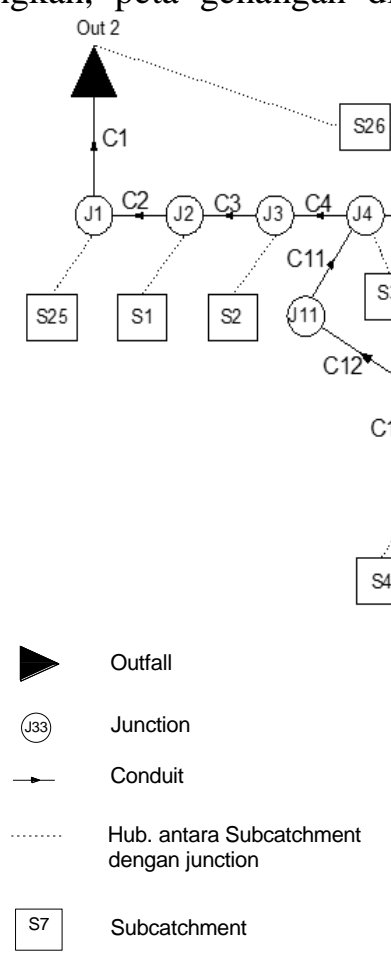

Lasiana kota Kupang seperti yang terlihat pada Gambar 6.

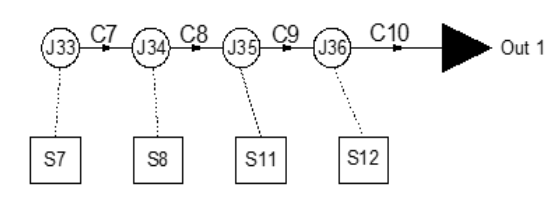

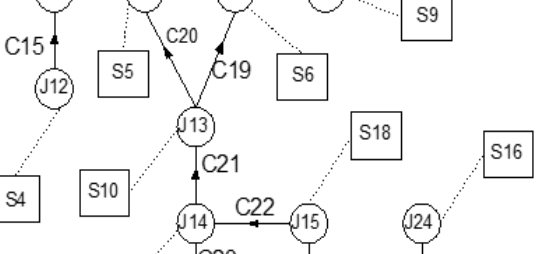

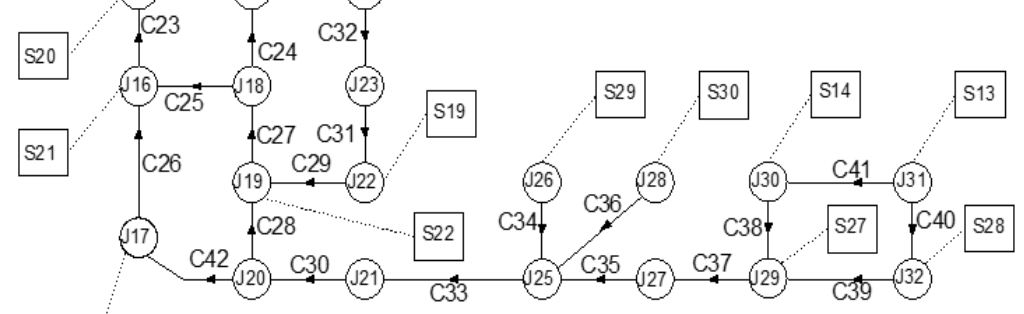

s23

Gambar 5. Skema Jaringan Drainase Dengan Kondisi Eksisting

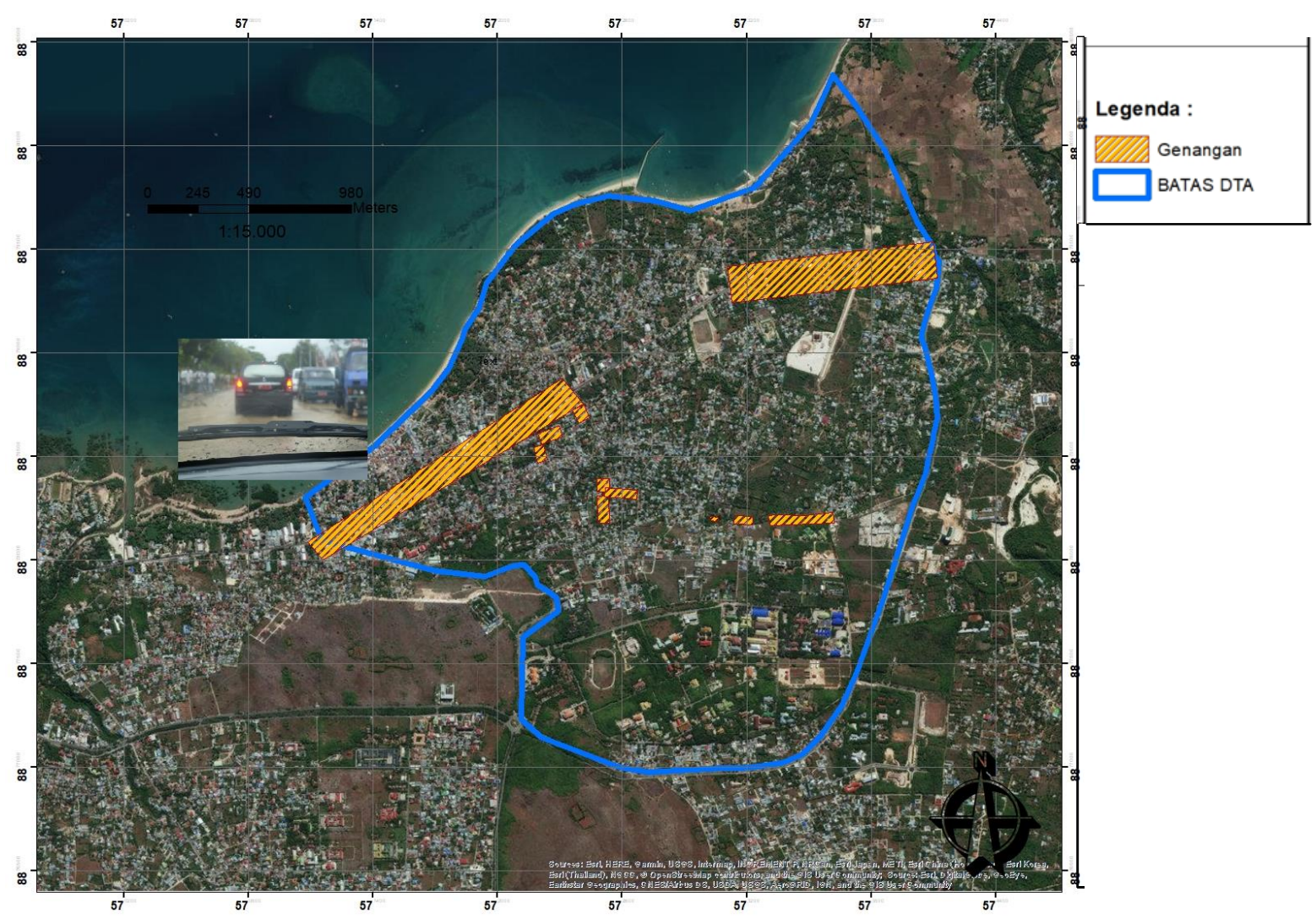

Gambar 6. Lokasi Genangan di DTA Oesapa - Lasiana 
Penelusuran banjir pada saluran dengan SWMM, memakai persamaan kontinuitas (konservasi massa), dan persamaan momentum untuk unsteady, gradually varied flow, yaitu persamaan Saint Venant (Rossman, 2015). Pemilihan penelusuran gelombang dinamis (Dynamic Wave Routing) untuk melakukan simulasi
SWMM ini, karena memberikan hasil yang secara teoritis paling akurat. Hasil running model SWMM untuk model sistem drainase dengan kondisi eksisting sebelum adanya struktur penanggulangan genangan dapat dilihat pada Gambar 7 di bawah ini:

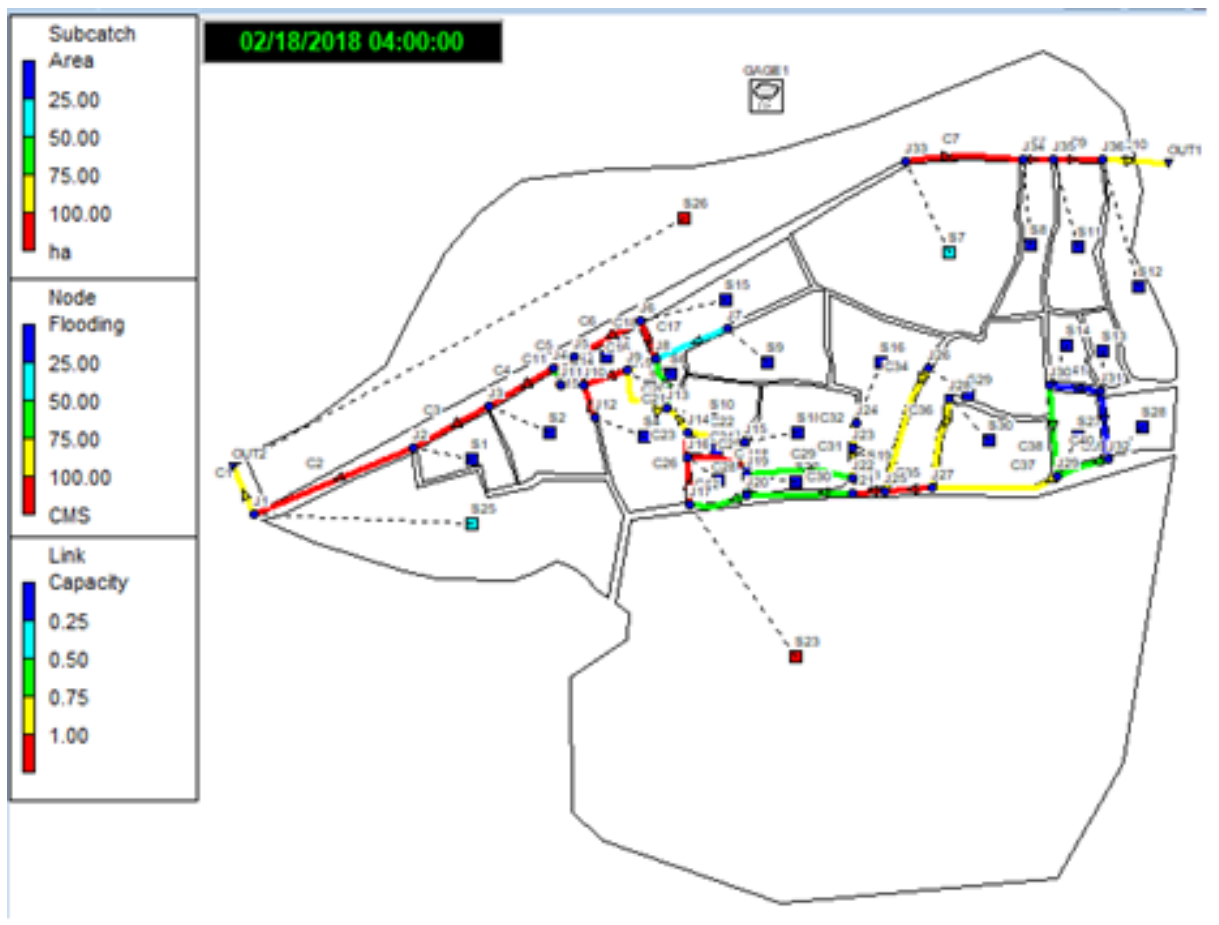

Gambar 7. Hasil Running Model SWMM untuk Skematisasi Sistem Drainase pada Kondisi Eksisting

Merujuk hasil simulasi model SWMM dengan kondisi di jaringan drainase eksisting menunjukkan beberapa ruas saluran/conduit berwarna merah yang berarti kapasitas saluran/conduit tersebut sudah tidak dapat menampung aliran air yang mengalir di dalamnya atau meluber. Hasil simulasi debit limpasan dan tinggi aliran air masing-masing saluran/conduit dapat dilihat pada Tabel 5 berikut.

Tabel 5 Hasil Simulasi Debit Limpasan Per Saluran Eksisting

\begin{tabular}{|c|c|c|c|c|c|c|}
\hline No & $\begin{array}{c}\text { Nama } \\
\text { Saluran }\end{array}$ & $\begin{array}{c}\mathrm{h}_{\text {sal }} \\
(\mathrm{m})\end{array}$ & $\begin{array}{c}\mathrm{h}_{\text {makx }} \\
(\mathrm{m})\end{array}$ & $\begin{array}{c}\mathrm{V}_{\text {makx }} \\
(\mathrm{m} / \mathrm{det})\end{array}$ & $\begin{array}{c}\mathrm{Q}_{\text {makx }} \\
\left(\mathrm{m}^{3} / \mathrm{det}\right)\end{array}$ & Keterangan \\
\hline $\mathbf{( 1 )}$ & $\mathbf{( 2 )}$ & $\mathbf{( 3 )}$ & $\mathbf{( 4 )}$ & $\mathbf{( 5 )}$ & $\mathbf{( 6 )}$ & $\mathbf{( 7 )}$ \\
\hline 1 & $\mathrm{C} 1$ & 1.000 & 0.890 & 2.450 & 2.193 & Air tidak meluber \\
\hline 2 & $\mathrm{C} 2$ & 0.700 & 0.700 & 1.360 & 0.884 & Air meluber \\
\hline 3 & $\mathrm{C} 3$ & 0.700 & 0.700 & 1.160 & 0.779 & Air meluber \\
\hline 4 & $\mathrm{C} 4$ & 0.700 & 0.700 & 2.050 & 1.434 & Air meluber \\
\hline 5 & $\mathrm{C} 5$ & 0.700 & 0.700 & 3.630 & 2.538 & Air meluber \\
\hline 6 & $\mathrm{C} 6$ & 0.700 & 0.700 & 1.640 & 1.150 & Air meluber \\
\hline 7 & $\mathrm{C} 7$ & 0.700 & 0.700 & 2.020 & 1.413 & Air meluber \\
\hline 8 & $\mathrm{C} 8$ & 0.700 & 0.700 & 2.090 & 1.461 & Air meluber \\
\hline 9 & $\mathrm{C} 9$ & 0.700 & 0.700 & 1.560 & 1.093 & Air meluber \\
\hline 10 & $\mathrm{C} 10$ & 0.700 & 0.560 & 1.540 & 0.869 & Air tidak meluber \\
\hline 11 & $\mathrm{C} 11$ & 0.700 & 0.504 & 1.470 & 0.742 & Air tidak meluber \\
\hline 12 & $\mathrm{C} 12$ & 0.600 & 0.456 & 3.260 & 0.742 & Air tidak meluber \\
\hline 13 & $\mathrm{C} 13$ & 1.000 & 1.000 & 2.160 & 1.504 & Air meluber \\
\hline
\end{tabular}


Lanjutan Tabel 5 Hasil Simulasi Debit Limpasan Per Saluran Eksisting

\begin{tabular}{|c|c|c|c|c|c|c|}
\hline No & $\begin{array}{c}\text { Nama } \\
\text { Saluran }\end{array}$ & $\begin{array}{c}\mathrm{h}_{\text {sal }} \\
(\mathrm{m})\end{array}$ & $\begin{array}{c}\mathrm{h}_{\text {makx }} \\
(\mathrm{m})\end{array}$ & $\begin{array}{c}\mathrm{V}_{\text {makx }} \\
(\mathrm{m} / \mathrm{det})\end{array}$ & $\begin{array}{c}\mathrm{Q}_{\text {makx }} \\
\left(\mathrm{m}^{3} / \mathrm{det}\right)\end{array}$ & Keterangan \\
\hline 14 & $\mathrm{C} 14$ & 1.000 & 1.000 & 2.420 & 1.690 & Air meluber \\
\hline 15 & $\mathrm{C} 15$ & 1.000 & 1.000 & 1.650 & 0.658 & Air meluber \\
\hline 16 & $\mathrm{C} 16$ & 1.000 & 0.790 & 1.660 & 1.051 & Air tidak meluber \\
\hline 17 & $\mathrm{C} 17$ & 1.000 & 0.450 & 2.510 & 0.912 & Air tidak meluber \\
\hline 18 & $\mathrm{C} 18$ & 0.550 & 0.550 & 1.560 & 0.368 & Air meluber \\
\hline 19 & $\mathrm{C} 19$ & 1.000 & 0.730 & 1.590 & 0.341 & Air tidak meluber \\
\hline 20 & $\mathrm{C} 20$ & 1.000 & 0.940 & 2.240 & 1.580 & Air tidak meluber \\
\hline 21 & $\mathrm{C} 21$ & 1.000 & 0.940 & 2.240 & 1.421 & Air tidak meluber \\
\hline 22 & $\mathrm{C} 22$ & 1.000 & 0.800 & 2.500 & 1.747 & Air tidak meluber \\
\hline 23 & $\mathrm{C} 23$ & 1.000 & 1.000 & 4.500 & 2.703 & Air meluber \\
\hline 24 & $\mathrm{C} 24$ & 0.600 & 0.594 & 2.270 & 0.770 & Air tidak meluber \\
\hline 25 & $\mathrm{C} 25$ & 0.600 & 0.600 & 2.410 & 1.011 & Air meluber \\
\hline 26 & $\mathrm{C} 26$ & 0.600 & 0.600 & 3.220 & 1.685 & Air meluber \\
\hline 27 & $\mathrm{C} 27$ & 1.000 & 0.470 & 2.760 & 1.786 & Air tidak meluber \\
\hline 28 & $\mathrm{C} 28$ & 1.400 & 0.378 & 2.930 & 0.699 & Air tidak meluber \\
\hline 29 & $\mathrm{C} 29$ & 0.700 & 0.511 & 2.250 & 0.800 & Air tidak meluber \\
\hline 30 & $\mathrm{C} 30$ & 1.000 & 0.720 & 2.810 & 1.406 & Air tidak meluber \\
\hline 31 & $\mathrm{C} 31$ & 0.700 & 0.616 & 1.640 & 0.675 & Air tidak meluber \\
\hline 32 & $\mathrm{C} 32$ & 0.700 & 0.616 & 1.580 & 0.676 & Air tidak meluber \\
\hline 33 & $\mathrm{C} 33$ & 1.000 & 1.000 & 3.270 & 2.291 & Air meluber \\
\hline 34 & $\mathrm{C} 34$ & 0.600 & 0.576 & 2.810 & 1.134 & Air tidak meluber \\
\hline 35 & $\mathrm{C} 35$ & 1.000 & 1.000 & 2.890 & 1.732 & Air meluber \\
\hline 36 & $\mathrm{C} 36$ & 0.600 & 0.468 & 1.430 & 0.469 & Air tidak meluber \\
\hline 37 & $\mathrm{C} 37$ & 1.000 & 1.000 & 1.470 & 1.474 & Air meluber \\
\hline 38 & $\mathrm{C} 38$ & 0.800 & 0.488 & 1.130 & 0.470 & Air tidak meluber \\
\hline 39 & $\mathrm{C} 39$ & 1.000 & 0.620 & 0.880 & 0.546 & Air tidak meluber \\
\hline 40 & $\mathrm{C} 40$ & 0.800 & 0.168 & 1.440 & 0.209 & Air tidak meluber \\
\hline 41 & $\mathrm{C} 41$ & 0.800 & 0.136 & 1.140 & 0.129 & Air tidak meluber \\
\hline 42 & $\mathrm{C} 42$ & 1.000 & 0.720 & 0.990 & 0.708 & Air tidak meluber \\
\hline & & & & & & \\
\hline
\end{tabular}

Hasil Perhitungan

Tabel 5 di atas merupakan hasil simulasi model SWMM pada jaringan drainase eksisting dengan intensitas hujan kala ulang 5 tahun, didapatkan 18 dari 42 saluran/conduit eksisting sudah tidak dapat menampung air limpasan yang terjadi. Dari hasil simulasi SWMM, air dalam saluran akan meluber jika tinggi aliran air maksimal $\left(\mathrm{h}_{\max }\right)$ dalam saluran eksisting sama dengan tinggi dari saluran eksisting $\left(\mathrm{h}_{\text {sal }}\right)$. Lokasi genangan tersebut akan menjadi dasar

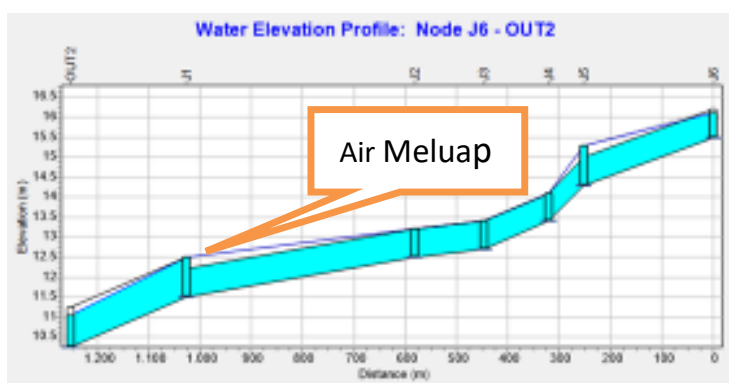

Gambar 8. Hasil simulasi kondisi eksisting pada conduit $\mathrm{C} 6-\mathrm{C} 5-\mathrm{C} 4-\mathrm{C} 3-\mathrm{C} 2-\mathrm{C} 1$ (node J6-J5-J4J3-J2-J1-Out2) penanggulangan genangan berbasis konservasi berupa penempatan struktur kolam retensi dan struktur sumur resapan. Dengan demikian maka, limpasan permukaan air hujan pada sub DTA-sub DTA dapat ditampung sementara dan atau diresapkan terlebih dahulu sebelum masuk ke dalam saluran drainase.

Profil muka air pada beberapa titik lokasi genangan hasil simulasi SWMM juga dapat dilihat pada gambar berikut.

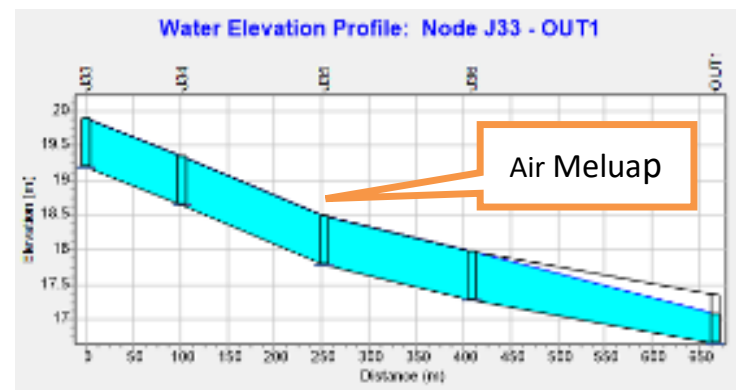

Gambar 9. Hasil simulasi kondisi eksisting pada conduit C7- C8-C9-C10 (node J33-J34J35-J36-Out1) 


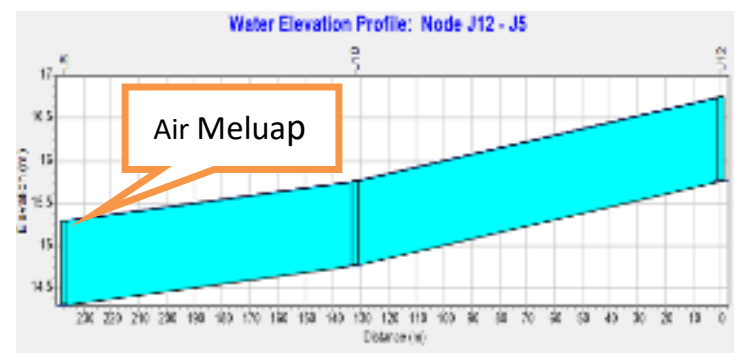

Gambar 10. Hasil simulasi kondisi eksisting pada conduit C15- C13 (node J12-J10-J5)

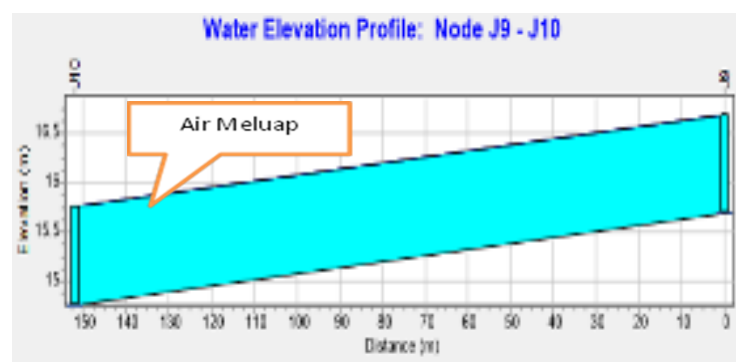

Gambar 11. Hasil simulasi kondisi eksisting pada conduit $\mathrm{C} 14$ (node J9-J10)

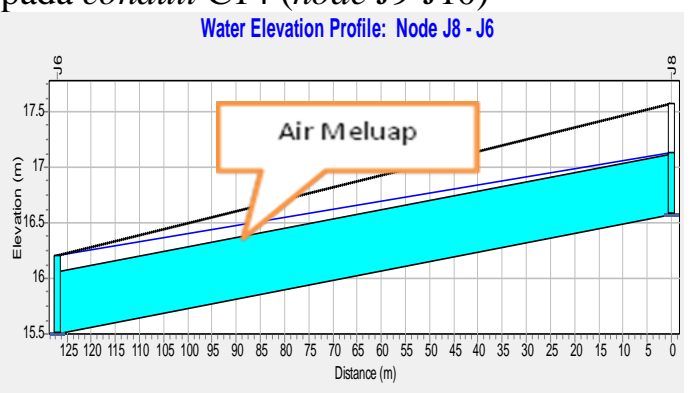

Gambar 12. Hasil simulasi kondisi eksisting pada conduit $\mathrm{C} 18$ (node J8-J6)

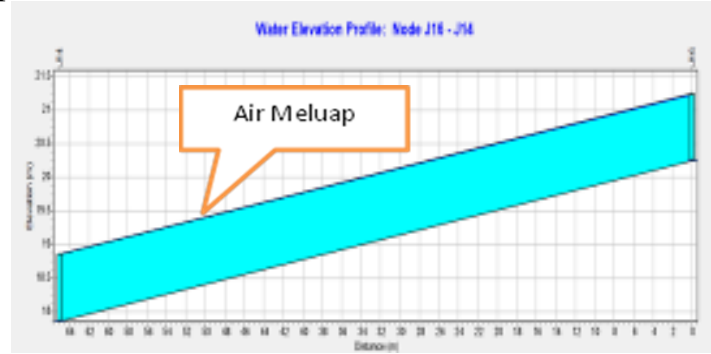

Gambar 13. Hasil simulasi kondisi eksisting pada conduit $\mathrm{C} 23$ (node J16-J14)

\section{Perencanaan Kolam Retensi, Sumur Resapan dan Peningkatan Kapasitas Saluran}

\section{Kolam Retensi}

Kolam retensi ini dibangun bukan hanya sebagai upaya pengendalian genangan tetapi juga sebagai upaya konservasi air. Dalam studi ini, kolam retensi direncanakan supaya dapat menyimpan sekaligus mengendalikan limpasan permukaan yang berasal dari hujan

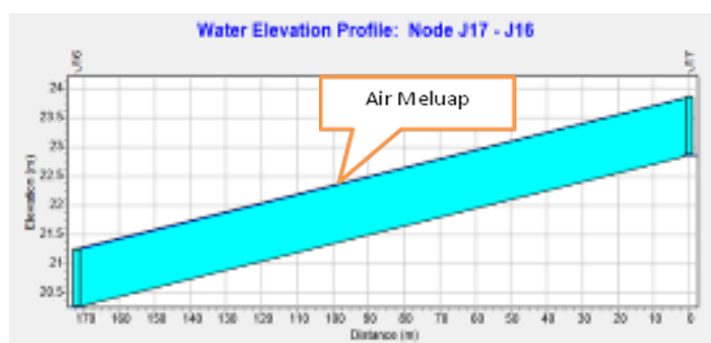

Gambar 14. Hasil simulasi kondisi eksisting pada conduit $\mathrm{C} 26$ (node $\mathrm{J} 17-\mathrm{J} 16$ )

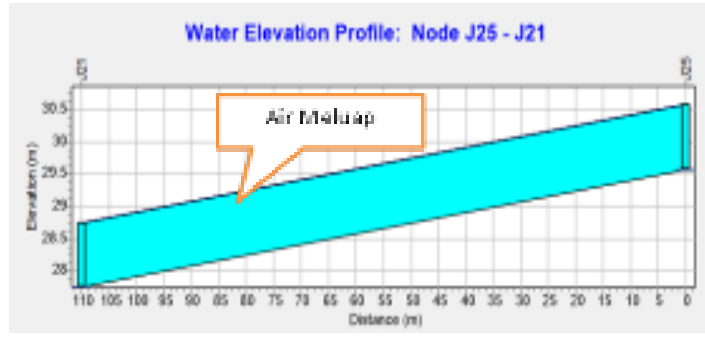

Gambar 15. Hasil simulasi kondisi eksisting pada conduit $\mathrm{C} 33$ (node $\mathrm{J} 25-\mathrm{J} 21$ )

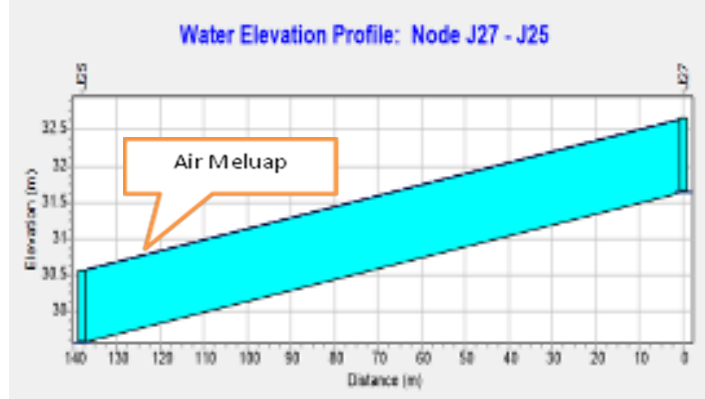

Gambar 16. Hasil simulasi kondisi eksisting pada conduit $\mathrm{C} 35$ (node J27-J25)

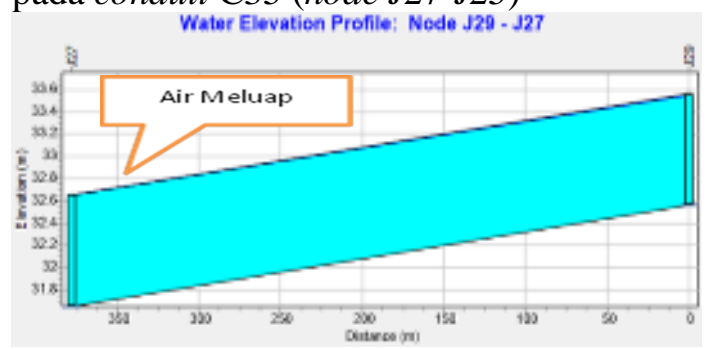

Gambar 17. Hasil simulasi kondisi eksisting pada conduit $\mathrm{C} 37$ (node J29-J27)

sehingga beban aliran yang masuk ke dalam saluran-saluran drainase menjadi berkurang. Limpasan air yang masuk ke dalam kolam retensi menjadi tertahan dan sebagian lagi meresap ke dalam tanah dan keluar melalui pelimpah (spillway) apabila sudah melewati kapasitas tampungan kolam. Kolam retensi yang direncanakan ini berukuran 160 meter x 100 meter dan kedalaman 3 meter. Tipikal kolam retensi seperti Gambar 18 berikut. 


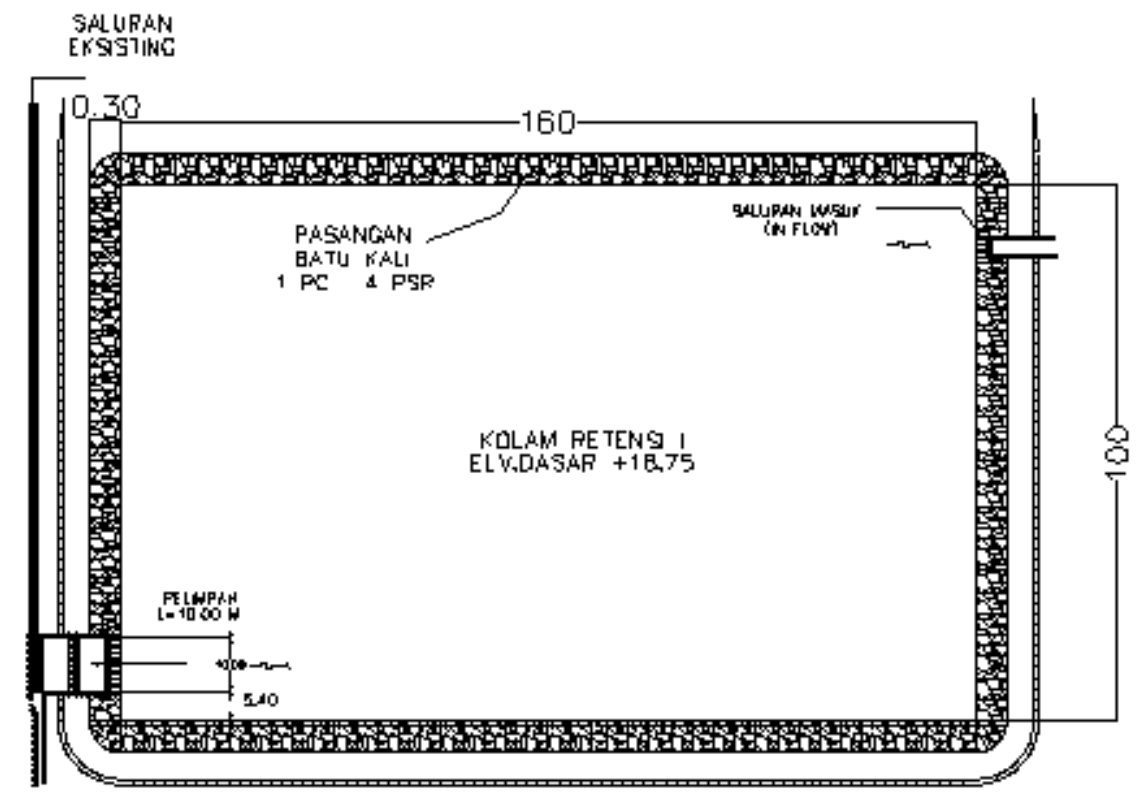

Gambar 18. Denah Kolam Retensi

\section{Sumur Resapan}

Sumur resapan dalam studi ini merupakan alternatif lain setelah penerapan kolam retensi yang bertujuan untuk mengurangi limpasan air permukaaan dan juga sebagai upaya konservasi. Penerapan sumur resapan ini menjadi lebih cocok dibandingkan dengan penerapan kolam retensi apabila penempatannya di lokasi yang merupakan kawasan padat penduduk. Sumur resapan yang direncanakan ini, ditempatkan di masing-masing pekarangan rumah penduduk. Dimensi dari sumur resapan sangat ditentukan oleh beberapa faktor berikut:

- Luas daerah tadah

- Koefisien permeabilitas tanah

- Tinggi muka air tanah

- Intensitas hujan

Volume dan efisiensi sumur resapan dapat dihitung berdasarkan keseimbangan air yang masuk ke sumur dan juga air yang meresap ke dalam tanah (Sunjoto,1988) dan dapat dihitung sebagai berikut:

a. Debit resapan pada sumur $\left(Q_{o}\right)$ :

$$
\begin{array}{ll}
\mathrm{L}= & 3.0 \mathrm{~m} \\
\mathrm{k}= & 5.96 \times 10^{-4} \mathrm{~cm} / \mathrm{det}=5.96 \times 10^{-6} \mathrm{~m} / \mathrm{det} \\
\mathrm{H} & =3.0 \mathrm{~m} \\
\mathrm{r} & =0.50 \mathrm{~m} \\
\mathrm{~T} & =1.3106 \mathrm{jam}=4718.0707 \text { detik }
\end{array}
$$

$$
\begin{aligned}
Q_{0} & =\frac{2 \pi L K H}{\ln \left[\frac{L}{2 R}+\sqrt{\left.1+\left(\frac{L}{2 R}\right)^{2}\right]}\right.} \\
& =\frac{2 \times 3.14 \times 3.00 \times 5.96 \times 10^{-6}}{\ln \left[\frac{3.00}{2 \times 0.50}+\sqrt{1+\left(\frac{3.00}{2 \times 0.50}\right)^{2}}\right]} \\
& =1.854 \times 10^{-4} \mathrm{~m}^{3} / \text { detik }
\end{aligned}
$$

b. Volume air hujan yang meresap $\left(\mathrm{V}_{\text {rsp }}\right)$

$$
\begin{aligned}
Q_{o} & =1.854 \times 10^{-4} \mathrm{~m}^{3} / \mathrm{det} \\
\mathrm{T} & =1.3106 \mathrm{jam}=4718.071 \text { detik } \\
\mathrm{V}_{\text {rsp }}= & \mathrm{Q}_{0} \times \mathrm{T} \\
= & 1.854 \times 10^{-4} \times 4718.071= \\
& 0.8748 \mathrm{~m}^{3}
\end{aligned}
$$

c. Kapasitas per unit sumur resapan

$$
\begin{aligned}
\mathrm{Vs} & =\pi \times \mathrm{r}^{2} \times \mathrm{t} \\
& =3.14 \times 0.5^{2} \times 3=2.355 \mathrm{~m}^{3}
\end{aligned}
$$

Jika per unit sumur dapat meresapkan air hujan sebesar $0.8748 \mathrm{~m}^{3}$, maka kapasitas total sumur adalah:

$$
\begin{aligned}
\text { Vtotal } & =\mathrm{V}_{\mathrm{s}}+\mathrm{V}_{\text {rsp }} \\
& =2.355+0.8748=3.23 \mathrm{~m}^{3}
\end{aligned}
$$

Sehingga debit yang bisa tertampung oleh sumur resapan dalam waktu 1.3106 jam adalah: 


$$
\begin{aligned}
\mathrm{Q}_{\mathrm{s}} & =\frac{\mathrm{V}_{\mathrm{tot}}}{\mathrm{T}} \\
& =\frac{3.23}{47718.071}=6.77 \times 10^{-5} \mathrm{~m}^{3} / \text { detik }
\end{aligned}
$$

Jika rata-rata luas tadah atap rumah di lokasi studi ini adalah $82 \mathrm{~m}^{2}$ (bila dianggap rumahnya tipe 45), maka volume limpasan hujan dari tiap atap dapat dihitung sebagai berikut:

$$
\begin{aligned}
\text { Vol }= & 0.278 \times \mathrm{C} \times \mathrm{I} \times \mathrm{A} \times \mathrm{T} \\
= & 0.278 \times 0.95 \times 6.30 \times 10^{-6} \times 84 \times \\
& 7200 \\
= & 0.80 \mathrm{~m}^{3}
\end{aligned}
$$

Dengan demikian kinerja per unit sumur resapan dapat dihitung:

$$
\begin{aligned}
& =\frac{V_{\text {tot sumur }}}{V_{\text {per atap }}} \\
& =\frac{3.23}{0.80}=4.04 \approx 4 \text { atap (rumah) }
\end{aligned}
$$

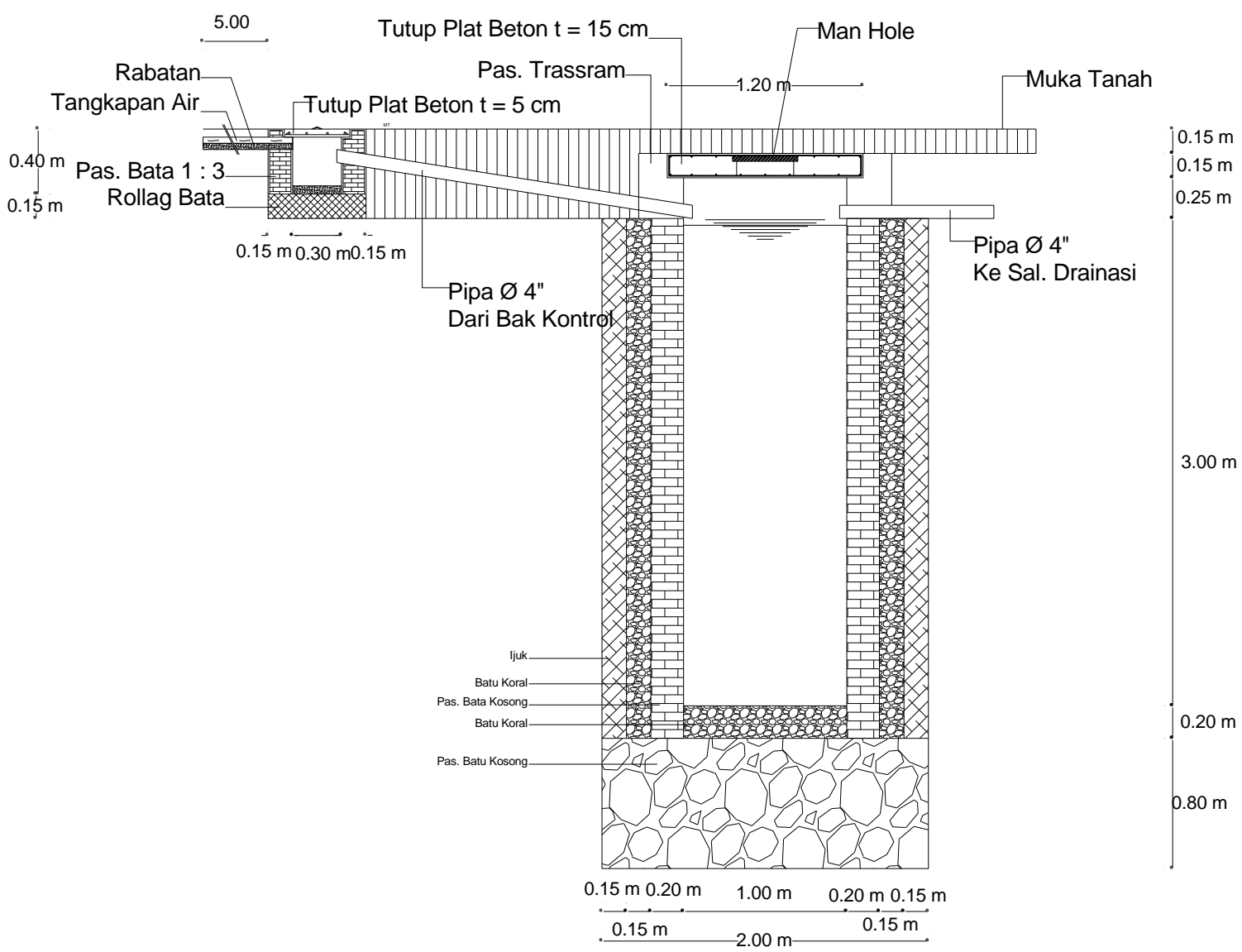

Gambar 19. Gambar Potongan Sumur Resapan

\section{Peningkatan Kapasitas Saluran}

Peningkatkan kapasitas saluran eksisting ini dapat menjadi alternatif pilihan yang paling terakhir dalam rangka penanggulangan banjir/genangan di lokasi studi. Peningkatan kapasitas saluran dengan melebarkan/meninggikan dimensi saluran haruslah tetap mempertimbangkan kondisi dan kebutuhan yang ada di lapangan.
Dimensi saluran eksisting pada lokasi studi yang rencananya mau dilebarkan/ditinggikan seperti yang terlihat pada Gambar 20 berikut sedangkan, ukuran pelebaran/peninggian dimensi saluran eksisting dapat dilihat pada Tabel 7 berikut. 
Tabel 7 Rencana Pelebaran/Peninggian Dimensi Saluran Eksisting

\begin{tabular}{|l|c|c|c|c|c|c|}
\hline \multirow{2}{*}{ No } & \multirow{2}{*}{$\begin{array}{c}\text { Nama } \\
\text { Saluran }\end{array}$} & \multirow{2}{*}{ Panjang Saluran } & \multicolumn{2}{|c|}{ Dimensi Eksisting } & \multicolumn{2}{|c|}{ Rencana Dimensi Baru } \\
\cline { 4 - 6 } & & & Lebar Dasar & Tinggi & Lebar Dasar & Tinggi \\
\hline 1. & $\mathrm{C} 2$ & $445 \mathrm{M}$ & $1.00 \mathrm{M}$ & $0.70 \mathrm{M}$ & $1.60 \mathrm{M}$ & $0.80 \mathrm{M}$ \\
2. & $\mathrm{C} 3$ & $135 \mathrm{M}$ & $1.00 \mathrm{M}$ & $0.70 \mathrm{M}$ & $1.60 \mathrm{M}$ & $0.80 \mathrm{M}$ \\
3. & $\mathrm{C} 4$ & $126 \mathrm{M}$ & $1.00 \mathrm{M}$ & $0.70 \mathrm{M}$ & $1.60 \mathrm{M}$ & $0.80 \mathrm{M}$ \\
\hline
\end{tabular}

Sumber : Hasil Perhitungan

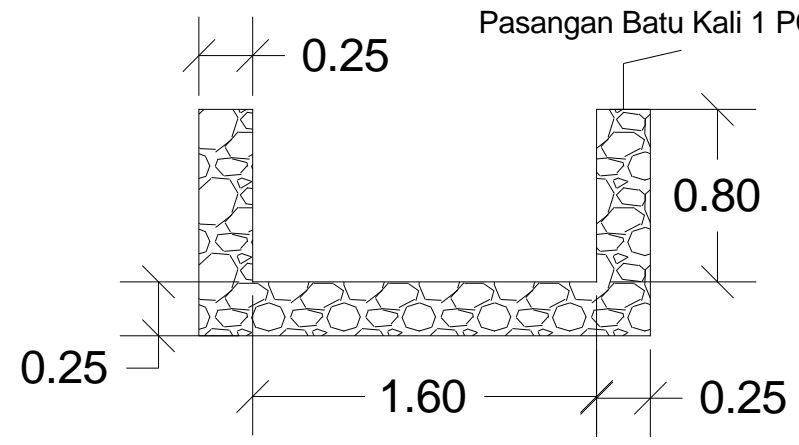

Gambar 20. Gambar Potongan Rencana Saluran Baru

Skematisasi Sistem Drainase dengan Penerapan Unit Kolam Retensi, Unit Sumur Resapan dan Peningkatan Kapasitas Saluran

Setelah merencanakan unit kolam retensi, sumur resapan dan juga peningkatan kapasitas saluran eksisting pada lokasi studi, selanjutnya bisa dilakukan simulasi model penanggulangan genangan berbasis konservasi pada hujan kala ulang 5 tahun.

Skema jaringan rencana penanggulangan genangan di lokasi studi seperti di Gambar 21, sedangkan hasil running model SWMM untuk kondisi penanggulangan genangan pada lokasi studi seperti terlihat pada Gambar 22 berikut.

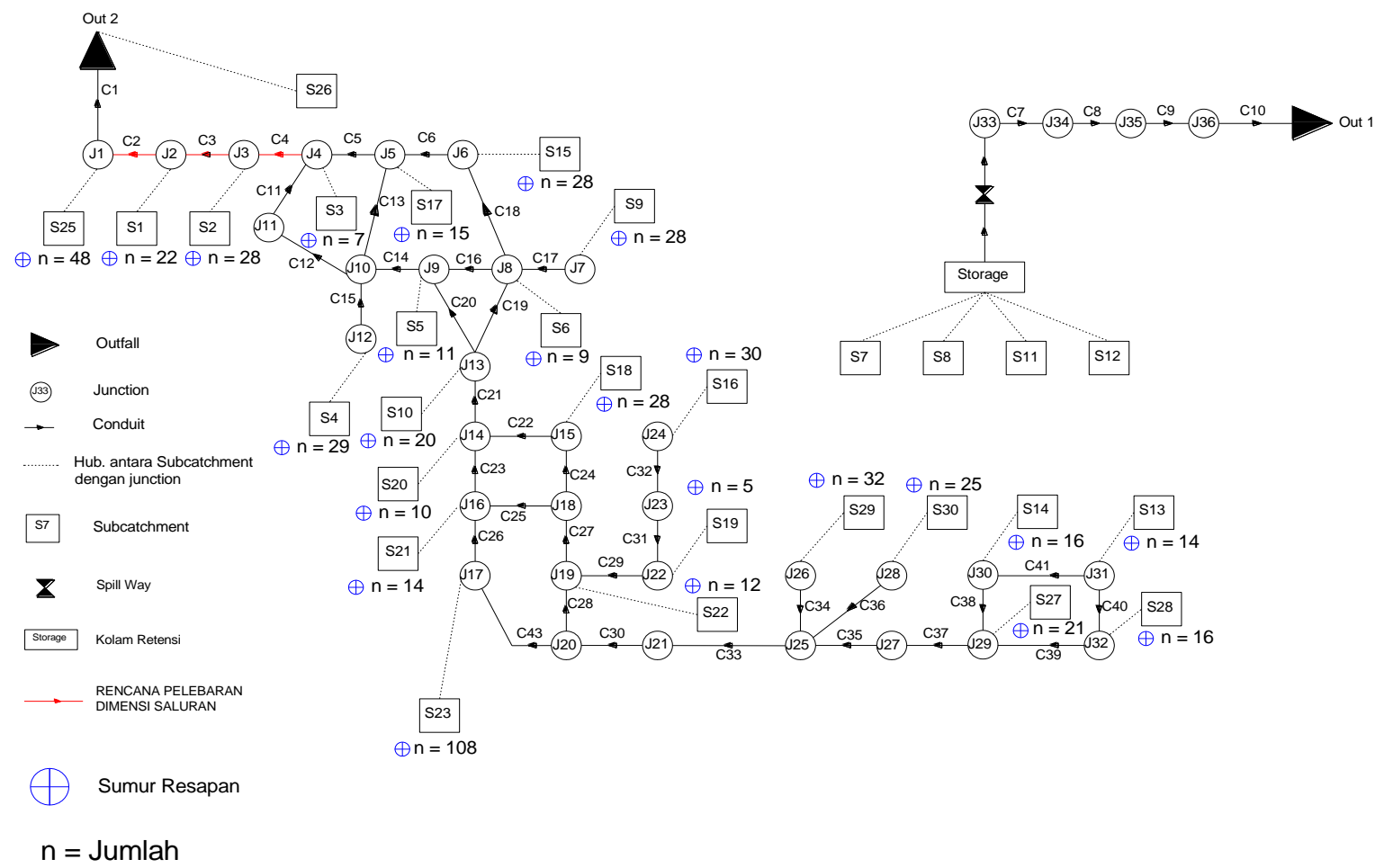

Gambar 21. Skema Jaringan Drainase dengan Penempatan Kolam Retensi, Sumur Resapan dan Peningkatan Kapasitas Saluran 


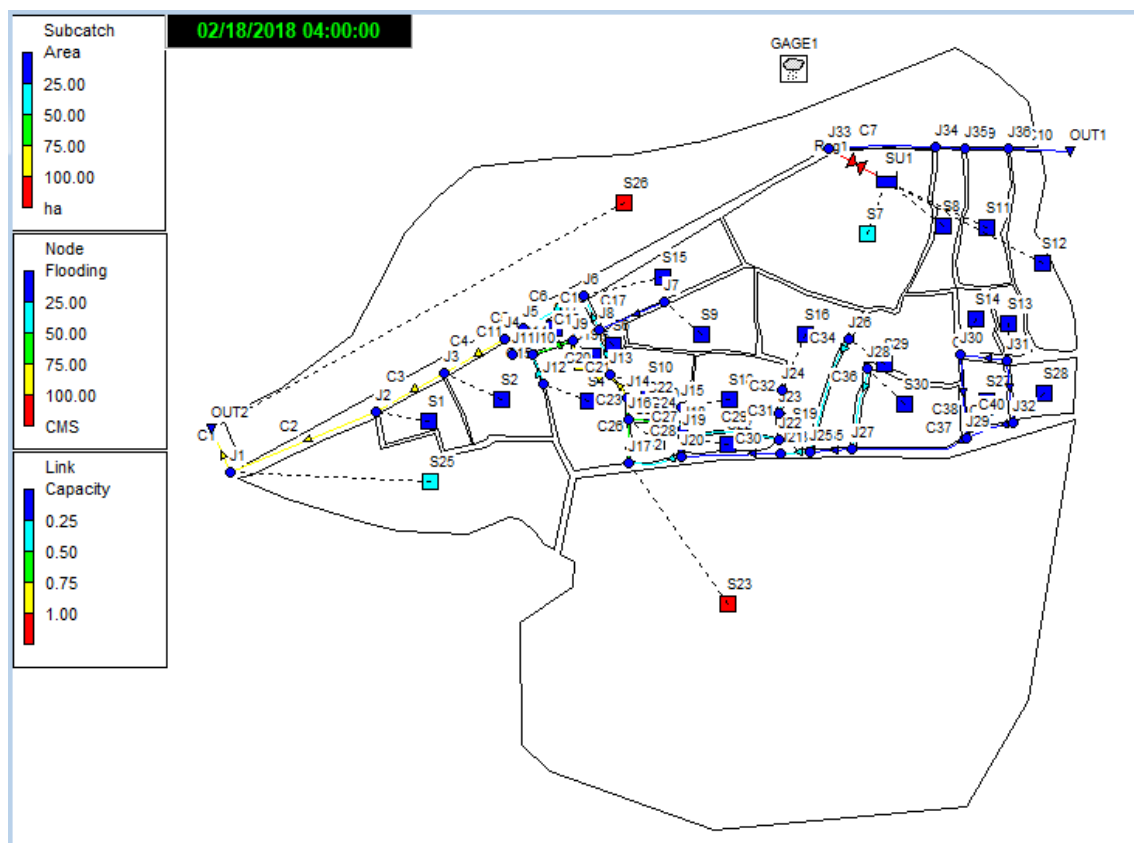

Gambar 22. Hasil Running Model SWMM untuk Skematisasi Sistem Drainase pada Kondisi Penanggulangan Genangan

Merujuk hasil running model SWMM pada kondisi penanggulangan genangan menunjukkan saluran/conduit (link capacity) tidak lagi berwarna merah yang menandakan kapasitas saluran/conduit tersebut sudah mampu menampung aliran air yang mengalir di dalamnya atau tidak meluber lagi. Hasil running SWMM dapat menampilkan perbandingan hidrograf pada sebelum dan sesudah penanggulangan genangan di saluran $\mathrm{C} 10$ (Outlet akhir 1) dan $\mathrm{Cl}$ (outlet akhir 2), sebagaimana pada Gambar 23 dan Gambar 24.

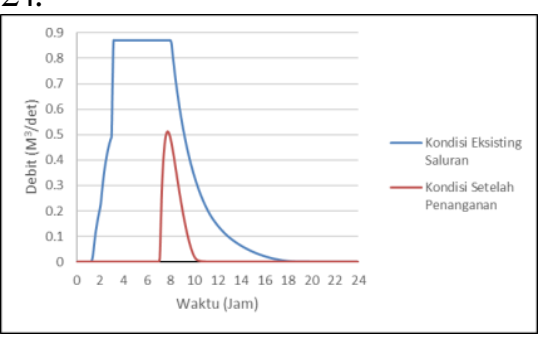

Gambar 23. Perbandingan hidrograf hasil simulasi sebelum dan sesudah penaggulangan genangan pada conduit C10 (outlet akhir 1)

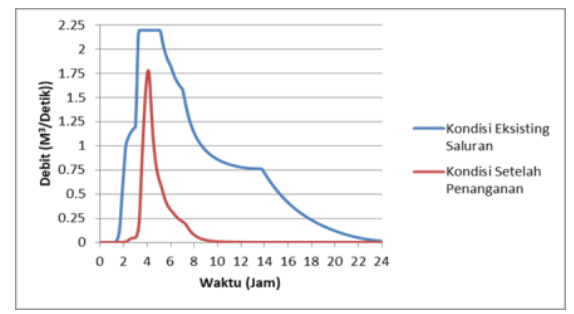

Gambar 24. Perbandingan hidrograf hasil simulasi sebelum dan sesudah penaggulangan genangan pada conduit $\mathrm{C} 1$ (outlet akhir 2)
Pada saluran $\mathrm{C} 10$, terjadilah penurunan debit puncaknya dari $0.869 \mathrm{~m}^{3} /$ detik menjadi $0.5122 \mathrm{~m}^{3} /$ detik (turun $41 \%$ ) sedangkan pada saluran $\mathrm{C} 1$, terjadi penurunan debit puncak dari $2.193 \mathrm{~m}^{3} /$ detik menjadi $1.777 \mathrm{~m}^{3} /$ detik (turun $18.96 \%$ )

Profil muka air di saluran yang menuju ke outlet terakhir sebelum dan sesudah penerapan kolam retensi, sumur resapan dan peningkatan kapasitas saluran bisa dilihat pada Gambar 25 dan Gambar 26 berikut.

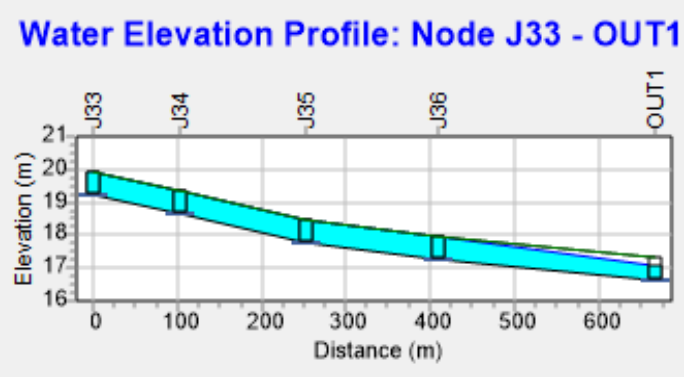

Water Elevation Profile: Node J33 - OUT

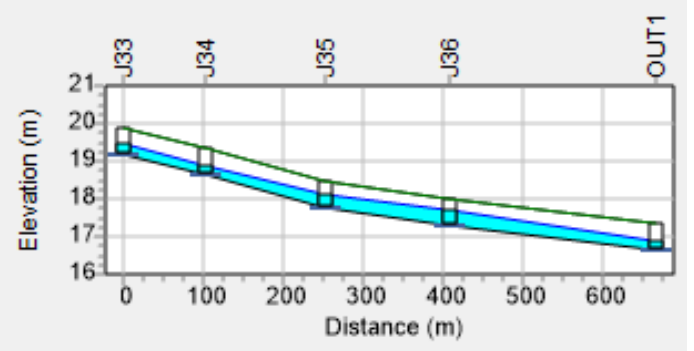

Gambar 25. Perbandingan profil muka air pada simpul J33-Out1 kondisi eksisting (atas) dan sesudah penanggulangan genangan (bawah) 


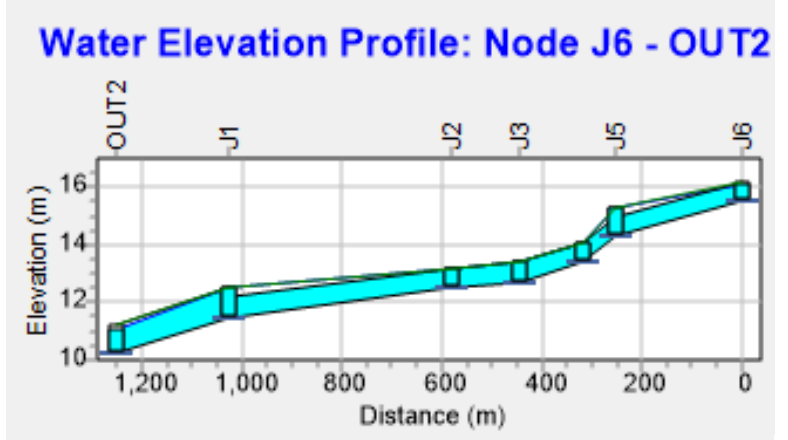

Water Elevation Profile: Node J6 - OUT2

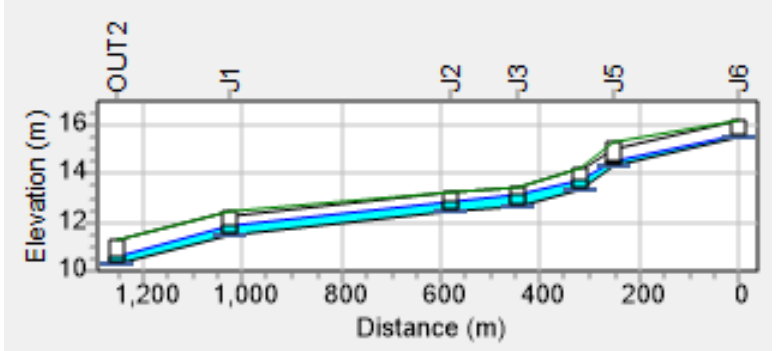

Gambar 26. Perbandingan profil muka air pada simpul J6-Out2 kondisi eksisting (atas) dan sesudah penanggulangan genangan (bawah)

\section{KESIMPULAN DAN SARAN \\ Kesimpulan}

Dari hasil perhitungan dan analisa yang telah dilakukan sebelumnya maka dapat ditarik kesimpulan sebagai berikut:

1. Kapasitas saluran drainase kondisi eksisting pada lokasi studi tidak mampu menampung hujan dengan kala ulang 5 tahun sehingga mengakibatkan genangan di 18 titik.

2. Berdasarkan kondisi di lokasi studi, maka penanggulangan genangan yang berbasis konservasi dilakukan dengan menerapkan:

a. Kolam retensi

- Kolam retensi yang berukuran 160 meter x 100 meter dengan kedalaman 3 meter.

- Penempatannya tetap memperhatikan jarak dengan bangunan lainnya.

b. Sumur resapan

- Sumur resapan berbentuk lingkaran, berkedalaman 3 meter, berdiameter 1 meter, memiliki dinding yang terbuat dari pasangan batu bata kosong tanpa diplester.

- Jumlah yang terpasang di sub DTA ada 587 unit. c. Peningkatan kapasitas saluran

Melebarkan dimensi saluran eksisting menjadi 1.600 meter x 0.800 meter sepanjang 706 meter.

Penerapan unit kolam retensi dan sumur resapan untuk mereduksi limpasan air hujan di tiap - tiap sub DTA sangat efektif sekali dan juga dapat berfungsi sebagai konservasi air tanah.

\section{Saran}

Upaya penanggulangan banjir/genangan di lokasi studi perlu memperhatikan hal-hal berikut:

1. Perlu adanya kesadaran penuh masyarakat setempat untuk memelihara serta merawat saluran drainase yang ada secara berkala dengan selalu siap melakukan pembersihan sampah dan sedimen terutama pada saatsaat menjelang musim hujan.

2. Kepada instansi yang terkait dapat diusulkan untuk mensyaratkan pembuatan sumur resapan untuk para pengembang perumahan pada saat pengurusan IMB karena, sumur resapan ini sangat bermanfaat sekali untuk konservasi air tanah dan juga bisa berfungsi mengurangi limpasan air hujan sehingga dapat mengurangi genangan yang akawasan perumahan padat penduduk.

\section{DAFTAR PUSTAKA}

Lo Russo. S, 2009, Groundwater in the Urban Environment: Management Needs and Planning Strategies, American Journal of Environmental Sciences

Rossman,L.A.,2015. Storm Water Management Model User's Manual Version5.1. Cincinnati, OH:U.S. Environmental Protection Agency.

Sosrodarsono,S.danTakeda,K. 2003. Hidrologi Untuk Pengairan. Pradnya Paramita. Jakarta.

Sri Harto. 2000. Hidrologi, Teori-MasalahPenyelesaian. Yogyakarta: Nafiri Offset.

Sunyoto, S. 1988. Optimasi Sumur Resapan Air Hujan Sebagai Salah Satu Usaha Pencegahan Intrusi Air Laut. Fakultas Teknik UGM. Yogyakarta. 